\title{
The Moral Logic and Growth of Suicide Terrorism
}

$S_{\text {uicide attack is the most virulent and horrifying form of terror- }}$ ism in the world today. The mere rumor of an impending suicide attack can throw thousands of people into panic. This occurred during a Shi'a procession in Iraq in late August 2005, causing hundreds of deaths. Although suicide attacks account for a minority of all terrorist acts, they are responsible for a majority of all terrorism-related casualties, and the rate of attacks is rising rapidly across the globe (see figures 1 and 2). During 2000-2004, there were 472 suicide attacks in 22 countries, killing more than 7,000 and wounding tens of thousands. Most have been carried out by Islamist groups claiming religious motivation, also known as jihadis. Rand Corp. vice president and terrorism analyst Bruce Hoffman has found that 80 percent of suicide attacks since 1968 occurred after the September 11 attacks, with jihadis representing 31 of the 35 responsible groups. ${ }^{1}$ More suicide attacks occurred in 2004 than in any previous year, ${ }^{2}$ and 2005 has proven even more deadly, with attacks in Iraq alone averaging more than one per day, according to data gathered by the U.S. military. ${ }^{3}$ The July 2005 London and Sinai bombings, a second round of bombings at tourist destinations in Bali in October, coordinated hotel bombings in Jordan in November, the arrival of suicide bombings in Bangladesh in December, a record year of attacks in Afghanistan, and daily bombings in Iraq have spurred renewed interest in suicide terrorism, with recent analyses stressing the strategic logic, organizational structure, and rational calculation involved. ${ }^{4}$

Scott Atran is director of research in anthropology at France's Centre National de la Recherche Scientifique (CNRS) and a visiting professor of psychology and public policy at the University of Michigan. Background research was supported by the U.S. Air Force Office of Scientific Research, the National Science Foundation, and CNRS. The author would like to thank Khalil Shikaki, Rohan Gunaratna, and Noor Huda Ismail for help in the field and Marc Sageman, Reuven Paz, Jessica Stern, and Bruce Hoffman for relevant data and ideas.

(C) 2006 by The Center for Strategic and International Studies and the Massachusetts Institute of Technology The Washington Quarterly • 29:2 pp. 127-147. 


\section{Figure I: Suicide Attacks Worldwide, Annualized by Decade}

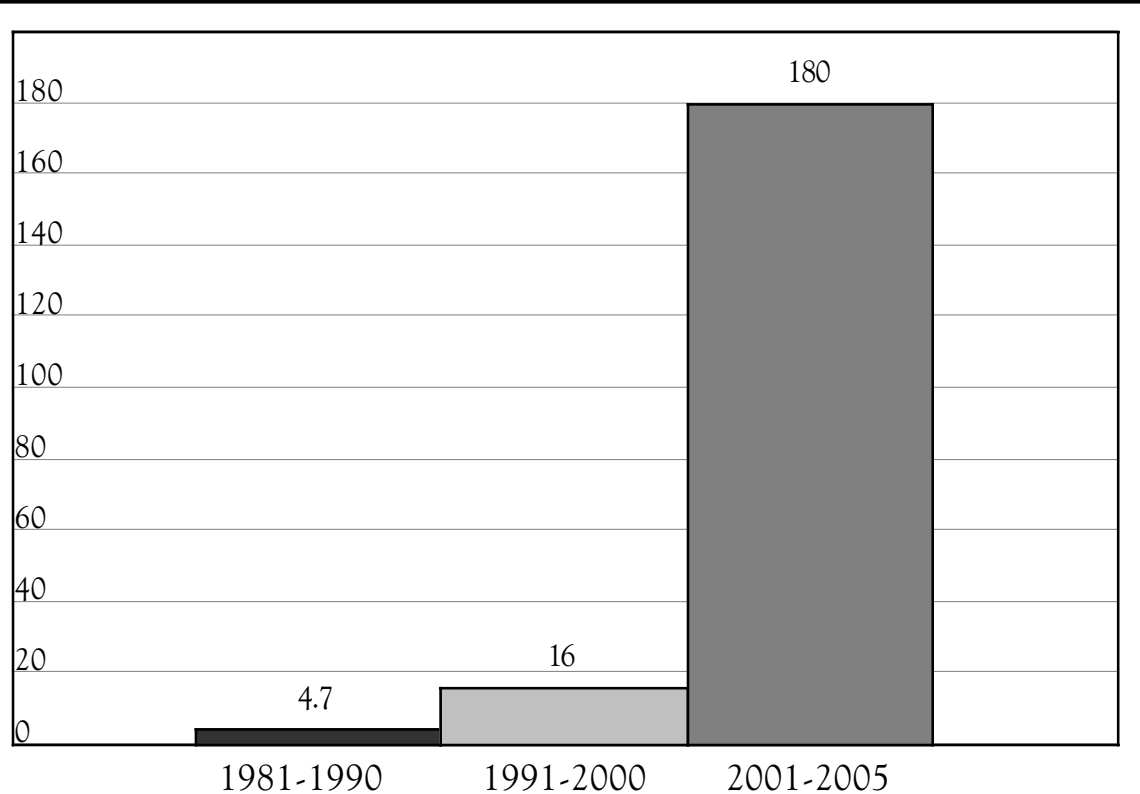

Whereas they once primarily consisted of organized campaigns by militarily weak forces aiming to end the perceived occupation of their homeland, as argued by University of Chicago political scientist Robert Pape in Dying to Win: The Strategic Logic of Suicide Terrorism, ${ }^{5}$ suicide attacks today serve as banner actions for a thoroughly modern, global diaspora inspired by religion and claiming the role of vanguard for a massive, media-driven transnational political awakening. Living mostly in the diaspora and undeterred by the threat of retaliation against original home populations, jihadis, who are frequently middle-class, secularly well educated, but often "born-again" radical Islamists, including converts from Christianity, embrace apocalyptic visions for humanity's violent salvation. In Muslim countries and across western Europe, bright and idealistic Muslim youth, even more than the marginalized and dispossessed, internalize the jihadi story, illustrated on satellite television and the Internet with the ubiquitous images of social injustice and political repression with which much of the Muslim world's bulging immigrant and youth populations intimately identifies. From the suburbs of Paris to the jungles of Indonesia, I have interviewed culturally uprooted and politically restless youth who echo a stunningly simplified and decontextualized message of martyrdom for the sake of global jihad as life's noblest cause. They are increasingly as willing and even eager to die as they are to kill.

The policy implications of this change in the motivation, organization, and calculation of suicide terrorism may be as novel as hitherto neglected. 


\section{Figure 2: Suicide Attacks Worldwide, 200I-2005}

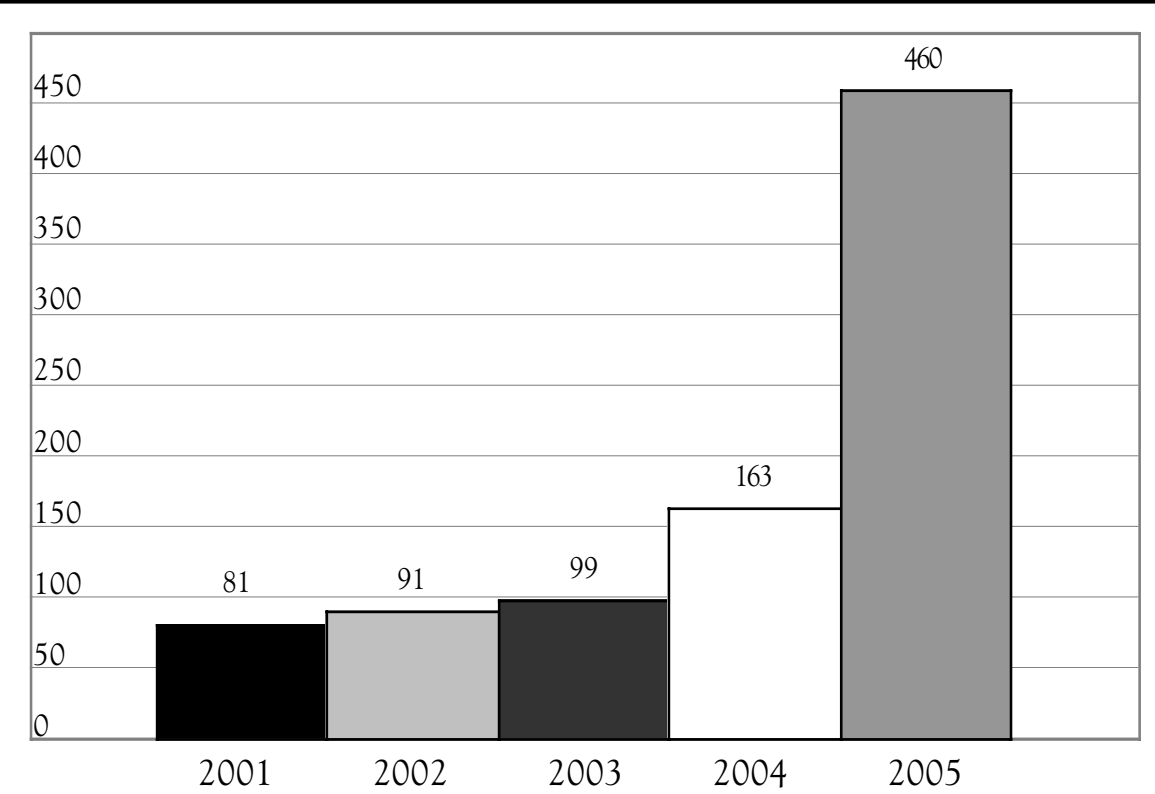

Many analysts continue to claim that jihadism caters to the destitute and depraved, the craven and criminal, or those who "hate freedom." Politicians and pundits have asserted that jihadism is nihilistic and immoral, with no real program or humanity. Yet, jihadism is none of these things. Do we really understand the causes of today's suicide terrorism? Do suicide attacks stem mainly from a political cause, such as military occupation? Do they need a strong organization, such as $\mathrm{Al}$ Qaeda? What else could be done to turn the rising tide of martyrdom?

\section{It's Not Just for Politics Anymore}

In Dying to Win, Pape claims that foreign occupation is the root cause of suicide terrorism. The rise in attacks correlates with U.S. military occupation of countries whose governments tend to be authoritarian and unresponsive to popular demands. Analyzing data on 315 suicide attacks from 1980 to 2003, he asserts that the common thread linking 95 percent of all suicide attacks around the world is not religion or ideology, but rather a clear, strategic, political objective. They are organized campaigns to compel a modern democracy, principally the United States, to withdraw military forces from a group's perceived homeland. Al Qaeda supposedly fits this model, being driven primarily by the efforts of Osama bin Laden and those sympathetic to his cause to expel the United States from the Arab heartland-Saudi 
Arabia, Palestine, Egypt, and Iraq-and ultimately from all Muslim countries. On September 11, 2001, for example, 15 of the 19 suicide attackers came from Saudi Arabia, where nearly 5,000 U.S. combat troops were billeted at the time, with 7,000 more stationed elsewhere on the Arabian peninsula.

According to Pape's findings, suicide bombers come disproportionately from among the largely secular and educated middle classes that aspire to freedom and greater opportunities, yet see their hopes stymied by corrupt dictators and one-party elites acting in collusion with U.S. oil and other interests. On the surface, recent trends seem to bolster Pape's thesis. In October 2003, bin Laden warned in a televised video that European nations fighting in Iraq or Afghanistan would be fair game for attack. The next month, suicide bombings targeted the British consulate and HSBC Bank in Istanbul. In December 2003, jihadi Web sites were broadcasting "Iraqi Jihad, Hopes and Risks," ${ }^{6}$ a 42-page blueprint for strategically timing bombings to European political events, the first target of which became the March 2004 Spanish elections. (The bombers in these attacks blew themselves up with suicide belts later when cornered by police, and two Madrid plotters who escaped the police dragnet died as suicide bombers in Iraq in April 2005.)

In the last two years, suicide attackers have struck in 18 countries, mostly among U.S. allies linked to undemocratic regimes, such as Pakistan, Saudi Arabia, Uzbekistan, and Egypt, or in places with perceived occupations, such as the Palestinian territories, Chechnya, Kashmir, Afghanistan, and Iraq. In Iraq in 2004, there were more suicide attacks than in the entire world in any previous year of contemporary history, involving "martyrs" from 14 other Arab countries, ${ }^{7}$ as well as volunteers from all over Europe. Nevertheless, Pape's basic data, correlations, and conclusions about the causes of terrorism are problematic, outdated in the wake of the September 11 attacks and sometimes deeply misleading.

In broad terms, statistical regularity or predictability alone can only indicate correlations but never demonstrates cause. This study relies exclusively on the computation of statistical trends rather than complementing them with judgments gleaned from nonrandom interviews with the human subjects of study themselves. This dichotomy is unnecessary and even pernicious. ${ }^{8}$ Although one should not make the reciprocal mistake of taking personal accounts at face value, structured psychological interviews and systematic observations by anthropologists and other social scientists who participate in the lives of their informants can provide new and surprising alternatives to frame the collection of statistical data. ${ }^{9}$ More specifically, at least four critical flaws are embedded in the conclusions drawn from the data.

First, there is a concern with sampling. Pape continues to argue that "the leading instigator of suicide attacks is the Tamil Tigers in Sri Lanka, a Marx- 
ist-Leninist group whose members are from Hindu families but who are adamantly opposed to religion." 10 Yet, in the last three years, the Tigers and the other main secular and nationalist groups in Pape's sample, such as Turkey's Kurdistan Worker's Party (PKK), have carried out very few attacks or none at all. The Tigers have carried out only two confirmed suicide attacks since the beginning of 2002. Although they perhaps remain the leading single organizer of suicide attacks (77 in total), there have been more suicide attacks by various Iraqi groups in 2005 (where more than 400 attacks killed more than 2,000 people) than in the entire history of the Tigers. ${ }^{11}$ The Iraqi attacks have not been carried out through a particularly well-organized strategic operation, but rather via a loose, ad hoc constellation of many small bands that act on their own or come together for a single attack. ${ }^{12}$ There also appear to be clear and profound differences between secular nationalist groups such as the Tamil Tigers, who fight to expel occupiers from their homeland, and glo-
There were more suicide attacks in the last two years than between 1980 and 2003. bal jihadis, who fight against perceived global domination. For example, Tamil suicide operatives are actively selected by recruiters and cannot withdraw from planned operations without fear of retaliation against their families, ${ }^{13}$ whereas the martyrs of the Al Qaeda network are mostly self-recruiting and deeply committed to global ideology through strong network ties of friendship and kinship so that events anywhere in jihad's planetary theater may directly impact actions anywhere else.

Second, Pape's conclusions about suicide terrorism are both too narrow and too broad. On the narrow side, none of Pape's data indicate that conventional tactics are less useful than suicide attacks in cases where terrorists appear to have scored successes in liberating their homeland. ${ }^{14}$ For example, Israel exited southern Lebanon 14 years after Hizballah ceased to use suicide tactics, and the United States withdrew from Somalia after casualties suffered under conventional attack. The category of suicide terrorism today also proves to be too broad and motley a category to draw reliable conclusions about motivations and goals. For example, although the Tigers deserve their due in any inquiry on contemporary suicide terrorism, their relevance to the global diffusion of martyrdom operations is questionable.

Marc Sageman, a forensic psychiatrist and former intelligence case officer, has traced the links among more than 400 jihadis with ties to Al Qaeda. ${ }^{15}$ No significant demographic differences emerge between Sageman's global jihadi sample and Pape's more restricted sample of 71 terrorists who killed themselves between 1995 and 2004 in attacks sponsored or inspired 
by $\mathrm{Al}$ Qaeda. In other words, there seem to be no reliable differences between jihadi martyrs in particular and jihadis who fight in the name of global jihad more generally.

Third, rather than judging as Pape does the success of suicide tactics primarily by whether the sponsoring organization has helped to expel foreigners from its homeland, the broader strategic

There is a lingering misconception that martyrs are being directed by 'Al

Qaeda.' goal that suicide attacks seek may be to increase the sponsoring organization's political "market share" among its own potential supporters, that is, to broaden its political base among the population and narrow popular support for rival organizations. ${ }^{16}$ For example, the Hamas campaign of suicide bombings actually caused Israel to reoccupy Palestinian lands during the second intifada and not to withdraw, but levels of popular support for Hamas increased to rival and at times even surpass support for the Fatahdominated Palestinian Liberation Organization. ${ }^{17}$ Inciting the withdrawal of foreign forces is only one means of accomplishing that goal. Thus, the net effect of the suicide attacks was not to expel foreign forces but to increase the appeal of Hamas. Similarly, the net result of the September 11 attacks was substantially greater U.S. and foreign intervention in Muslim territories, although Al Qaeda's profile rose to the top of the global jihadi ranks.

Fourth, Pape's argument that suicide terrorism is unrelated or only marginally related to Salafi ideology employs an unfounded inference. Salafis believe that the hadith (oral traditions) and literal readings of the Qur'an are sufficient guides for social law and personal life. The most militant among them, the jihadis, believe that all contemporary majority-Muslim countries with the exception of Afghanistan under the Taliban have strayed from the true path of Islam and that the only way back is through violent jihad. Pape relies on statistics to show that "the presence of [U.S.] military forces for combat operations on the homeland of suicide terrorists is stronger than Islamic fundamentalism in predicting" whether someone will become an $\mathrm{Al}$ Qaeda suicide terrorist. ${ }^{18}$ According to Pape's analysis, nearly one-third of Pakistan's 150 million people are estimated to be Salafi, but the country has produced only two suicide terrorists, whereas Morocco has no Salafis, according to a single secondary source from 1993, but has produced 12 suicide terrorists.

Some of these statistics can be contested, whereas others need to be updated. For example, although Salafism may still lack wide popular support in Morocco, its appeal has grown steadily among the discontented in that 
country since the 1970s and especially after the return of the Afghan alumni in the 1990s. ${ }^{19}$ By the end of 2004, Pakistan had at least 10 suicide bombers in the country, apart from the dozens of suicide terrorists from Pakistan's Kashmiri groups that profess allegiance to global jihad. Similarly, the number of suicide terrorists in heavily Salafi Egypt has quadrupled over the figure presented in Pape's 2003 tables and has more than doubled in Indonesia. Uzbekistan, which had six suicide bombers in 2004 and which Pape listed as having no Salafi population, in fact has large numbers of mostly urban youth who now sympathize with Hizb ut-Tahrir, a radical Islamist movement largely unknown in Central Asia before the mid-1990s, whose proclaimed goal is jihad against the United States and the overthrow of existing political regimes and their replacement with a caliphate run on Salafi principles.

As a causal variable, however, "Salafi population in country of origin" is largely irrelevant to what is happening in the world today. Even if the sample's statistical reliability were

Most jihadis follow kin and colleagues more than they do orders from afar. to hold up for the years that Pape surveyed, suicide terrorism is a rapidly moving phenomenon that still involves relatively small numbers, the significance of which can shift dramatically in a relatively short period of time. Indeed, there were more suicide attacks in the last two years, roughly 600, than in Pape's entire sample between 1980 and 2003. The British-born bombers who attacked London in 2005 or the Malaysians who likely planned the latest Bali bombing belong to the fringe of a large and growing Muslim diaspora.

This changing jihadi landscape is revealed in the formation of the cell responsible for the 2004 Madrid train bombings. As early as October 2002, the substitute imam of the Takoua Mosque in Madrid was informing Spanish police under the codename "Cartagena" that a band of friends, unhappy with the mosque's seemingly moderate preachings, had begun calling themselves Al Haraka Salafiya (The Salafi Movement). According to Cartagena, they met "clandestinely, with no regularity or fixed place, by oral agreement and without any schedule, though usually on Fridays." Soon, the informal group of mostly homesick Moroccan descendants and émigrés "reached the conclusion that they had to undertake jihad." By November 2002, opinion within the group began to shift against "going to other countries to undertake jihad, when operations were possible in Morocco and Spain." 20 A detailed action plan only began to coalesce later the following year, however, around the time the Internet tract "Iraqi Jihad, Hopes and Risks" began to circulate a call for "two or three attacks ... to exploit the coming general 
elections in Spain in March 2004" on the Global Islamic Media Front Web site ${ }^{21}$ to which the Madrid plotters had been systematically logging on since the spring of 2003. The police reports show that targeting trains to force Spain out of the coalition in Iraq was only a late goal emanating from an informal network dedicated to the simple but diffuse project of undertaking jihad to defend and advance a Salafist vision of Islam.

When Egyptian Bedouin are dying to kill European tourists and the Egyptians who cater to them; when British citizens blow themselves up along with other British because of the country's involvement in Iraq and Afghanistan; when jihadis exclusively target co-religionists linked to the secular government in Bangladesh, which is not a particularly close friend of the United States or its allies; when Malaysian bombers kill Australians and Balinese Hindus in Indonesia as "self-defense" in a "clash of civilizations" between Islam and the United States; ${ }^{22}$ and when Arabs from more than a dozen countries rush to embrace death in Iraq in order to kill Shi'as, who are probably more supportive of Iran than they are of the United States, it is quite a stretch to identify the common thread as a secular struggle over foreign occupation of a homeland, unless "secular" covers transcendent ideologies, "foreign occupation" includes tourism, and "homeland" expands to at least three continents.

\section{Al Qaeda as Bogeyman}

Attributing the motivations to narrowly expelling foreign forces is not the only common misconception about today's suicide terrorists. There is a preferred interpretation and lingering misconception among leading pundits and politicians that contemporary martyrs around the world are being directed and organized by a specific "Al Qaeda" group. Al Qaeda leaders and operatives, they claim, are behind the coordinated bombings in London, Egypt, Iraq, and elsewhere. Yet, remnants of the mostly Egyptian hardcore around bin Laden have not managed a successful attack in three years, since the bombing in Djerba, Tunisia, in October 2002. In fact, they do not even know who many of the new terrorists are, much less be able to communicate with and direct them reliably.

Whither Al Qaeda? Only after the embassy bombings in Africa in 1998 did U.S. officials or anyone else begin referring to Al Qaeda as a worldwide terrorist organization led by bin Laden. It came from the somewhat contradictory testimony in United States vs. Usama Bin Laden, et al. in U.S. federal court in New York that same year. One detainee, Khalfan Khamis Mohamed, claimed never to have heard of an "Al Qaeda" group but recognized the term as a way of carrying out militant actions. Another, Jamal Ahmed Al-Fadl, said "the Al Qaeda group" had existed since "around '89."23 
Especially after the September 11 attacks, nationalist Islamist movements from Morocco to Indonesia, which had jealously guarded their independence, spiritually united under the $\mathrm{Al}$ Qaeda logo. Intense public attention on Al Qaeda encouraged homegrown groups only tenuously connected with bin Laden, if at all, to claim responsibility for attacks in Al Qaeda's name, to be taken more seriously both by friends and foes. Abu Mus'ab Al-Zarqawi's Iraq-based jihadi group, whose violent, anti-Shi'a policy was never bin Laden's, is a good example.

"Al Qaeda" terrorist actions are now chiefly executed by self-forming cells of friends that swarm for attack, then disappear or disperse to form new swarms. Independent studies by Nixon Center scholar Robert Leiken ${ }^{24}$ and Sageman show that more than 80 percent of known jihadis currently live in diaspora communities, which are often marginalized from the host society and physically disconnected from each other. Similar to the decentralized anarchist movement that terrorized the world a century ago, most jihadis follow kin and colleagues more than they do orders from afar. Their difficult-to-penetrate social networks consist of about 70 percent friends and 20 percent family. ${ }^{25}$

Yearning for a sense of community and a deeper meaning in life, small groups of friends and family from the same area "back home" bond as they surf Islamist Web sites and seek direction from Al Qaeda's inspiration. ${ }^{26}$ In the last five years, Web sites carrying Islamist messages have increased from less than 20 to more than $3,000,{ }^{27}$ with about 70 avowedly militant sites collectively forming a virtual jihadi university. In fact, an October 2005 posting by Ahmad Al-Wathiq bi-Llah, "deputy general emir" of the Al-Zarqawi-affiliated Global Islamic Media Front, reissued a 2003 announcement for the "Al Qaeda University of Jihad Studies ... a tangible reality for the enemies of the Nation and the Faith; a decentralized university without geographical borders, present in every place."28 "Graduates," he explains, pass through "faculties" that advance the cause of a global caliphate through morale boosting and bombings and specialize in "electronic jihad, media jihad, spiritual and financial jihad."

Although veteran jihadis may sometimes help trigger the newer groups into action, even information for the do-it-yourself explosives used in the Madrid and London bombings is available on the Internet. ${ }^{29}$ As in the case of the Madrid train bombers, even if all of the plotters are caught or kill themselves, it need not affect the ability of other groups to self-organize and 
stay motivated so that the movement does not die with them. The December 2003 Internet tract that foreshadowed the Madrid bombings inspired attacks that would force Spain's withdrawal from Iraq as a way to generate "huge pressure on the British presence, which [Prime Minister] Tony Blair could not overcome." ${ }^{30}$ When Blair did not follow suit, however, it appears that a mix of homegrown talent - three cricket friends of Pakistani origin: one married, one in college, one "born again," later joined by a convertfused by foreign-born incitement bombed London to press matters. Web sites such as that of the Global Islamic Media Front ${ }^{31}$ that host these tracts have become the new organizational agents in jihadi networks, replacing physical agents such as bin Laden. Even functioning central actors such as Zarqawi are effectively only co-leaders with the media sites that increasingly control the distribution of knowledge and resources.

The edited snippets and sound bites favored by today's mass media have been used with consummate skill by jihadi leaders and ideologues, beginning with bin Laden himself. As a result, deeply local and historically nuanced interpretations of religious canon have been flattened and homogenized across the Muslim world and beyond, in ways that have nothing in particular to do with actual Islamic tradition but everything to do with a polar reaction to perceived injustice in the prevailing unipolar world. At the same time, the historical narrative, however stilted or fictitious, translates personal and local ties within and across small groups into a profound connection with the wider Muslim community (ummah).

\section{Jihadis Are Not Nihilistic (Even If Apocalyptic)}

A third misconception is that those who carry out attacks in the name of $\mathrm{Al}$ Qaeda or through its inspiration do so mostly because the terrorist is desperate or a nihilist who, in the words of President George W. Bush, "hates freedom, rejects tolerance, and despises dissent" and wants only to replace the current mildly corrupt and undemocratic regimes with the terrorist's own far more authoritarian and arbitrary form of "evil." ${ }^{2}$ This is the thesis of the U.S. leadership. ${ }^{33}$ It is hopelessly tendentious and willfully blind. ${ }^{34}$

It is nonsense to claim that Al Qaeda and its sympathizers have no morality and simply want to annihilate Western civilization. In general, charges of nihilism against an adversary usually reflect ignorance of the adversary's moral framework or an attempt publicly to cast it as simply evil to mobilize domestic support for war. Even bin Laden has never preached destruction of Western culture or else, as he has taunted, "Why didn't we attack Sweden?"35 At every turn, bin Laden has earnestly sought moral justification for Al Qaeda's actions and demands. ${ }^{36}$ This includes his invocation of a fatwah 
published in May 2003 by radical Saudi cleric Hamid bin Al-Fahd permitting the use of nuclear weapons to inflict millions of casualties on the United States, unless Washington changes its foreign policy toward the Middle East and elsewhere in the Muslim world. ${ }^{37}$

One important post-September 11 development in global network jihad is that $\mathrm{Al}$ Qaeda splinters no longer consider themselves to be territorially rooted in supporting populations. Unconstrained by concrete concerns for what will happen to any population that supports them, deracinated jihadis can conceive of any manner of attack, including one leading to fulfillment of Al-Fahd's apocalyptic vision. Al Qaeda deputy Ayman Al-Zawahiri continues to urge jihadis everywhere to inflict the greatest possible damage and maximum casualties on the West, regardless of the time and effort required or of the immediate consequences.

To some extent, organizations that sponsor suicide terrorism are motivated to fight policies they abhor by hard-nosed calculations of the material costs and benefits associated with martyrdom actions. Al-Zawahiri argues in his "testament," Knights Under the Prophet's Banner, that "[t] he method of martyrdom operations [i]s the most successful way of inflicting damage against the opponent and the least costly to the mujahideen in casualties." 38 Increasing their organization's political market share, jihadi leaders point to the sacrifice of their best and brightest as signals of their costly commitment to their community. In September 2004, Sheikh Hamed Al-Betawi, a spiritual leader of Hamas, told me that "[o] ur people do not own airplanes and tanks, only human bombs. Those who undertake martyrdom actions are not hopeless or poor, but are the best of our people, educated, successful. They are intelligent, advanced combat techniques for fighting enemy occupation." 39

Yet, according to Harvard political scientist Jessica Stern, who has interviewed terrorists and those who sponsor them, holy wars are dependent first and foremost on redressing a deep pool of perceived humiliation, not just on military occupation per se and certainly not on simply nihilistic grounds. ${ }^{40}$ Al-Zawahiri decries globalization, including tourism, as cultural domination that degrades Muslims. Groups claiming responsibility for the July 2004 suicide bombings of hotel and market areas in Sharm el-Sheikh, Egypt, for example, did not simply wish to purge Egypt of foreign influence. Rather, the plotters or those sympathetic to them considered "that this operation was in response to the crimes committed by the forces of international evil, which are spilling the blood of Muslims in Iraq, Afghanistan and Chechnya." 41 
Inspiration for targeting tourists can be found in the recent online musings of Abu Mus'ab Al-Suri, the new global jihadi Web "star" and principal theoretician of "leaderless resistance," 42 who sets a top priority of targeting Western tourists. ${ }^{43}$ This tactic, initiated by Zawahiri, has become a mainstay of suicide attacks linked to Al Qaeda's primary ally in Southeast Asia, Jemaah Islamiyah (JI), most recently with the September 2005 Bali bombings. JI lieutenant Riduan Isamuddin, also known as Hambali, first decided to intervene in a local dispute between

We can no longer ignore the moral values and group dynamics that drive suicide terrorism. Muslims and Christians in the remote Indonesian Maluku islands to extend his brand of jihad to all of Indonesia and then, after the September 11 attacks, to globalize the jihad by enlisting suicide bombers to hit Western targets and interests, including the 2002 Bali bombings that killed more than 200, mostly tourists, and the 2003 attack on Jakarta's J.W. Marriott hotel.

In Iraq, the theme of humiliation, such as well-publicized U.S. military actions at Abu Ghraib prison, is important to understanding the Islamists' rage. As an observation from interviewing terrorists and those who inspire and care for them, individuals who opt for suicide attacks often seem motivated by values and small-group dynamics that trump rational self-interest. Violation of such values leads to moral outrage and seemingly irrational vengeance ("get the offender, even if it kills us"). Adherence to sacred values, which provides the moral foundations and faith of every society or sect that has endured for generations, ${ }^{44}$ ultimately leads to perceived moral obligations that appear to be irrational, such as martyrdom..$^{45}$ One is obliged to act "independently of the likelihood of success," 46 as in acts of heroism or terrorism, because believers could not live with themselves if they did not.

When our research team interviews would-be suicide bombers and their sponsors and when we survey their supporters, for example, Hamas students or students in Indonesian madrassas that have produced suicide bombers, we pose questions such as, "What if your family were to be killed in retaliation for your action?" or "What if your father were dying and your mother discovered your plans and asked you to delay until the family could recover?" Almost all answer along the lines that, although duty to family exists, duty to God cannot be postponed. The typical response to the question "What if your action resulted in no one's death but your own?" is, "God will love you just the same." When I posed these questions to the alleged emir of JI, Abu Bakr Ba'asyir, in Jakarta's Cipinang prison in August 2005, he re- 
sponded that martyrdom for the sake of jihad is the ultimate fardh 'ain, an inescapable individual obligation that trumps all others, including four of the five pillars of Islam (pilgrimage, almsgiving, fasting, prayer). This is a radically new interpretation of Islam, where only the profession of faith in Allah and his prophet counts as equal to jihad. What matters for Ba'asyir, as for most would-be martyrs and their sponsors whom I have interviewed, is the martyr's intention and commitment to God. ${ }^{47}$ It is inspired by love of one's group and by rage at those who would humiliate it, but certainly not blind rage.

The power of faith is something many understand at home but few deem worthy of consideration for enemies abroad. Yet, responses from jihadis, as well as their actions, suggest that sacred values are not entirely sensitive to standard political or economic calculations regarding costs or payoffs that come with undertaking martyrdom actions, nor are they readily translatable from one culture to another. Especially in Arab societies, where the culture of honor applies even to the humblest family as it once applied to the noblest families of the southern United States, ${ }^{48}$ witnessing the abuse of elders in front of their children, whether verbal insults at roadblocks or stripdowns during house searches, indelibly stains the memory and increases popular support for martyrdom actions. ${ }^{49}$ This can be true even if the person is witness only to an injured party living thousands of miles away, for example, an Indonesian observing events in the Palestinian territories on television or though the Internet. What may be considered standard police practice in the United States may warrant undying calls for revenge in another society. Moreover, when sacred values are at stake, traditional calculations of how to defeat or deter an enemy, for example, by invoking a democratic vote, providing material incentives to defect, or threatening massive retaliation against supporting populations, might not succeed.

\section{Policy Implications: Responding Transnationally}

Despite common popular misconceptions, suicide terrorists today are not motivated exclusively or primarily by foreign occupation, they are not directed by a central organization, and they are not nihilistic. Most suicide terrorists today are inspired by a global jihadism which, despite atavistic cultural elements, is a thoroughly modern movement filling the popular political void in Islamic communities left in the wake of discredited Western ideologies co-opted by corrupt local governments. Appeals to Muslim history and calls for a revival of the caliphate are widespread and heartfelt. To some extent, jihadism is also a countermovement to the ideological and corresponding military thrust ensconced, for example, in the National Security Strategy of the United States, which enshrines liberal democracy as the "single 
sustainable model of national development right and true for every person, in every society - and the duty of protecting these values against their enemies." 50

An alternative both to global jihadis and U.S. democracy promoters are those who support a more measured version of realism. This strategy would advocate returning to "offshore balancing," which would shift the burden of and recognition for managing the security of turbulent regions to regional powers. ${ }^{51}$ Pape favors this approach as the

The policy implications of this change may be as novel as hitherto neglected. only coherent strategy to minimize suicide terrorism and what it represents: unwanted domination. U.S. military superiority would permit a nod to others' primary interests in a region and help to maintain the latter's spheres of influence, while also allowing surgical interventions in cases where regional affairs got out of hand, for example, if oil supplies were threatened.

Would ending military adventures and support for corroded, undemocratic regimes, as Pape's analysis suggests, end the menace from suicide attack? As a long-term strategy, ending belligerent intervention in other people's affairs is likely a sound suggestion. In the short term, however, the link between ceasing military intervention and terminating suicide terrorism is less compelling. Simply exiting Iraq or Afghanistan today would not likely solve matters. Because the United States was not involved in Iraq or Afghanistan at the time, they could not have figured into the motivations for the September 11 attacks or earlier Al Qaeda suicide operations. After Spain's exit from Iraq, the threats to that country from jihadi terrorists did not abate: a subsequent bomb plot against a highspeed train to Toledo, as well as a plot by an independent Algerian cell to blow up the Madrid office of an antiterrorism judge, were both foiled by authorities, but they existed. Even the fact that the United States has largely withdrawn its military forces from Saudi Arabia seems to have done absolutely nothing to appease bin Laden. Moreover, his sympathizers see this as a concession, perhaps even inciting further attacks.

Both the realist and idealist approaches focus on the increasingly transected nation-state system, that is, on building nations or maintaining alliances among states. The problem, however, is transnational, and the solutions are not likely subject to any sovereign control, even that of the United States. What may be needed are new and varied forms of transnational associations that reach across cities and cyberspace, where decisions by and interactions among states represent only one of several possible dimensions. How, then, 
to deal with this deeply faith-inspired, decentralized, and self-adjusting global jihadi "market," where any small group of friends can freely shop for ideas or even for personnel and materials and any can inflict such widespread damage? A successful counterstrategy would have to act on at least three different levels: changing the motivations of potential recruits, disrupting sponsors' organizations, and undermining popular support.

\section{Recruits: Forget the Profiles, Understand the Cells}

In targeting potential recruits for suicide terrorism, it must be understood that terrorist attacks will not be prevented by trying to profile terrorists. They are not sufficiently different from everyone else. Insights into homegrown jiahdi attacks will have to come from understanding group dynamics, not individual psychology. Small-group dynamics can trump individual personality to produce horrific behavior in otherwise ordinary people.

Most jihadi cells are small in number, with eight members being most common. ${ }^{52}$ Although the members of each cell usually show remarkable homogeneity within the group (age, place of origin, residence, educational background, socioeconomic status, dietary preferences, etc.), there is little homogeneity across the jihadi diaspora. This renders attempts at profiling practically worthless. Cells are often spontaneously formed and self-mobilizing, with few direct physical contacts with other cells. Radicalization usually requires outside input from and interaction with the larger jihadi community. The Internet is taking over from the hands-on gurus of global jihad in radicalizing friends into pseudo-families for whom they will give their lives. Without the Internet, the extreme fragmentation and decentralization of the jihadi movement into a still functioning global network might not be possible.

This requires the careful monitoring rather than simple removal of existing jihadi Web sites. What is needed is a subtle infiltration of opportunities to create chat rooms, as well as physical support groups, which advance causes that can play to jihadi sentiments but that are not destructive, such as providing faith-based social services. The key is not to try to undermine the sacred values that inspire people to radical action or attempt to substitute one's own preferred values by forceful imposition or through propaganda. Our studies show that such tactics, as well as offers of instrumental incentives such as monetary compensation to forego martyrdom or make peace with an enemy, only incite further moral outrage and extreme behavior. ${ }^{53}$ Rather, the aim should be to show how deeply held sacred values can be channeled into less-belligerent paths. What has struck me in my interviews with mujahideen who have rejected suicide bombing is that they remain very committed to Salafi principles, with firm and deep religious beliefs. Those who seem to succeed best in convincing their brethren to forsake 
wanton killing of civilians do so by promoting alternative interpretations of Islamic principles that need not directly oppose Salafi teachings.

In his recent book, Unveiling Jemaah Islamiyah, one of JI's former top leaders, Nasir Abas, refutes what he believes to be a tendentious use of the Qur'an and hadith to justify suicide bombing and violence against fellow Muslims and civilians. (JI, similar to many of the militant Salafi groups that are sympathetic to $\mathrm{Al}$ Qaeda, is riddled with internal divisions over the wisdom of killing fellow Muslims and civilians.) "Not one verse in the [Qur'an] contains an order for Muslims to make war on people of another religion," Abas writes, "or that killing women, children and civilians can ever be proper, just or balanced. [The contrary belief] has only created discord in the Muslim community and has led non-Muslims to regard Islam as sadistic and cruel." ${ }^{54} \mathrm{He}$ reasons that the best way to turn altruistic suicide bombers who believe that what they are doing is sacred away from violence may be by religiously promoting competing sacred values, such as spreading the faith and promoting equal economic opportunity, as well as social and political advancement through educational achievement and personal piety. Sincere alternative appeals to sacred values could undermine consensus for violent jihad. The United States and its allies should quietly encourage this process without strangling it in open embrace.

\section{Organizations: Disrupting Decentralized Networks}

In targeting organizations that sponsor suicide terrorism, police action and intelligence are crucial, but the present mode of operations is not encouraging. Although traditionally hierarchical forms of military and intelligence command and control were suitable for large-scale operations against the Taliban and Al Qaeda's global organization, they are patently less effective now, even though classical means are still needed to prevent sanctuaries from reemerging. Impressions, such as the one that Central Intelligence Agency director Porter Goss reaffirmed in his inaugural address before Congress, that some specific group called $\mathrm{Al}$ Qaeda is out there planning bigger and better attacks are misleading. ${ }^{55}$ Ever more hierarchical and centralized management under a new national intelligence director to deal with increasingly decentralized terrorist networks may also be precisely the wrong way to go. According to former attorney general Edwin Meese, "It [will not] help matters to have a national intelligence director whose job is to prepare briefs to bring to the president every day or simply to coordinate intelligence products. What we could use is a facilitator to bring people and ideas together, not another operative." ${ }^{56}$

It may take a broad and elastic web of the diverse talent, tolerance, and spare conformity of our democracies, unbound from any nation's hegemony, 
calls to ruthlessness, or rigid rules of hierarchy, to snare the virtual hand of born-again jihad that guides suicide missions. Informal bonds may need to grow among diverse experts with idiosyncratic personal skills and the operational branches fighting terrorism, so that a phone call from an expert or operator in one country to another country can trigger specific responses without plodding through official channels-much the way globally networked jihadis now operate. This would help to convert fairly static responses into a dynamic system that would throw open the flow of information that would allow the intelligence and military communities' technological advantages to keep ahead of jihadi innovations without being mired in existing or reformed bureaucracies.

\section{Society: Diverting SyMpathy for MarTyrs}

In targeting popular support for suicide terrorism, it must be understood that terrorists depend, often quite consciously, on prodding those attacked into committing atrocious retaliatory acts, either deliberately or by a willingness to tolerate indefinitely horrific degrees and amounts of collateral damage to innocent bystanders. Historically and today, it is desecration of sacred places and perceived humiliation, even more than death and destruction, that has moved people to embrace violence. ${ }^{57}$

One strategic alternative is for the United States to do more of what it did in Aceh in early 2005 for tsunami victims, providing constructive investments of soft power that can generate longer-term relief from the need to use destructive and usually snowballing forms of hard power. ${ }^{58}$ U.S. tsunami relief arguably has been the one significant victory since the September 11 attacks in the struggle to prevent the enlistment of future terrorists for jihad (unfortunately, Kashmiri jihadi groups are the primary providers of assistance to the victims of Pakistan's recent earthquake). According to recent surveys conducted by the Pew Global Attitudes Project, Indonesian views of the United States, which were largely favorable before the U.S. invasion of Iraq, plummeted to 15 percent immediately afterward. ${ }^{59}$ Yet, the study shows that, since the rescue and relief role that the United States played in concert with other nations, international associations, and nongovernmental organizations after the tsunami, favorable attitudes toward the United States among Indonesians have risen to 38 percent. ${ }^{60}$ Concurrently, popular support for combating terrorism has doubled from 23 percent in 2003 to 50 percent in 2005. Indonesia is now one of the few nations where a majority ( 59 percent, up from 25 percent in 2003) believes that the United States can act in other nations' interests. Although these polls indicate that popular sentiment remains volatile, the bright side is that such instability suggests that the anti-Americanism that helps sustain the jihadi cult of martyrdom could yet be reversed. 


\section{Embracing Complexity}

Those who believe suicide terrorism can be explained by a single political root cause, such as the presence of foreign military forces or the absence of democracy, ignore psychological motivations, including religious inspirations, which can trump rational self-interest to produce horrific or heroic behavior in ordinary people. Those who believe that some central organization such as the old $\mathrm{Al}$ Qaeda directs such suicide terrorists ignore the small-group dynamics involving friends and family that form the diaspora cell of brotherhood and camaraderie on which the rising tide of martyrdom actions is based. Finally, those who simply dismiss jihadis as nihilists risk developing policies based on faulty assumptions that seek to challenge deeply held religious beliefs, rather than more effectively channel them to less-violent expressions.

Simple explanations and solutions, based mostly on familiar research and policy paradigms but no first-hand knowledge or field experience capable of challenging them, may be more appealing and easier to grasp. They are liable to fail, however, because they ignore the underlying moral values and group dynamics that drive jihadis to suicide terrorism. "Know thine enemy" is not a call for therapy but for a better understanding of who out there is dying to kill and why. Understanding that can help decisionmakers devise organizational and ideological solutions to defuse the threat of martyrdom.

\section{Notes}

1. Bruce Hoffman, "Security for a New Century," Washington, D.C., September 23, 2005 (briefing for Senate Foreign Affairs Committee staff).

2. Scott Atran, "Suicide Terrorism Database, 2004," http://www.sitemaker.umich.edu/ satran/files/suicide_terrorism_database_2004.xls.

3. Neil Macdonald, "Suicide Attack Every Day in the New Iraq," Financial Times, July 14, 2005, http://news.ft.com/cms/s/7c74abf8-f495-11d9-9dd1-00000e2511c8.html; Chris Tomlinson, "Fewer Suicide Bombings in Iraq in November," Associated Press, December 1, 2005.

4. Jim Giles and Michael Hopkin, "Psychologists Warn of More Suicide Attacks in the Wake of London Bombs," Nature, July 21, 2005, pp. 308-309.

5. Robert Pape, Dying to Win: The Strategic Logic of Suicide Terrorism (New York: Random House, 2005).

6. Reuven Paz, "Qa'idat al-Jihad, Iraq and Madrid," PRISM Special Dispatches on Global Jihad, March 13, 2004, http://www.e-prism.org/images/PRISM_Special_dispatch_no_12.pdf.

7. Reuven Paz, "Arab Volunteers Killed in Iraq," PRISM Special Dispatches on Global Jihad, March 3, 2005, http://www.e-prism.org/images/PRISM_no_1_vol_3__Arabs_killed_in_Iraq.pdf.

8. For representations of these two poles in the field of terrorism studies, see Marc Sageman, Understanding Terror Networks (Philadelphia: University of Pennsylvania 
Press, 2004); Jessica Stern, Terror in the Name of God (New York: HarperCollins, 2003). Both approaches yield important insights that may be enhanced by a coordination of efforts, which our common project with the National Science Foundation aims to accomplish.

9. For detailed examples of how cultural reframing of hypotheses can thoroughly undermine the presumed validity of statistical trends, no matter how significant and reliable those trends appear to be, see Scott Atran, Douglas Medin, and Norbert Ross, "The Cultural Mind: Ecological Decision Making and Cultural Modeling Within and Across Populations," Psychological Review 112 (2005): 744-776.

10. Robert Pape, "Blowing Up an Assumption," New York Times, May 18, 2005, p. A29.

11. Pape does not consider coordinated attacks launched around the same time as separate attacks. Even so, according to S.W.A.B. Daulagala, Sri Lanka's chief inspector of police, in total, 262 Tamil Tigers launched suicide attacks. Data presented to the Technical Experts Workshop on Suicide Terrorism, Organization for Security and Cooperation in Europe, May 20, 2005.

12 Dexter Filkins, "Profusion of Rebel Groups Helps Them Survive in Iraq," New York Times, December 2, 2005, p. A1.

13. Selliah Ignasius Yoganathan, "Rise and Decline of Suicide Terrorism in Sri Lanka," paper presented to the NATO Advanced Workshop on "The Strategic Threat from Suicide Terrorism," Lisbon, June 11, 2004.

14. Joshua Sinai, "The Unsettling Lure of Suicide Terrorism," Washington Times, June 19, 2005, http://www.washingtontimes.com/books/20050618-115922-1289r.htm.

15. Sageman, Understanding Terror Networks (updated with data presented to World Federation of Scientists Permanent Monitoring Panel on Terrorism, Erice, Italy, May 8, 2005).

16. Mia Bloom, Dying to Kill: The Allure of Suicide Terrorism (New York: Columbia University Press, 2005).

17. See Palestinian Center for Policy and Survey Research, http://www.pcpsr.org/survey/survey.html (political tracking polls of Palestinian popular opinion for the last seven years).

18. Pape, Dying to Win, p. 103.

19. Anouar Boukhars, "Origins of Militancy and Salafism in Morocco," Jamestown Terrorism Monitor, June 17, 2005, http://jamestown.org/terrorism/news/article.php? articleid $=2369722$.

20. "Las notas del Confidente 'Cartagena' Preuban Que la Policia Controlaba la Cúpula del 11-M" [Notes from the police informant "Cartagena" prove that the police were controlling the ringleader of March 11], http://www.belt.es/noticias/2005/junio/01/ 11-M.asp.

21. See Paz, "Qa'idat al-Jihad, Iraq and Madrid."

22. Scott Atran, "The Emir: An Interview With Abu Bakr Ba'asyir, Alleged Leader of the Southeast Asian Jemaah Islamiyah Organization," Jamestown Foundation Spotlight on Terrorism, September 15, 2005, http://jamestown.org/terrorism/news/ article.php? articleid $=2369782$.

23. United States of America v. Usama bin Laden, et al., February 6, 2001, http:// cryptome.org/usa-v-ubl-02.htm (defendant Jamal Ahmed Al-Fadl); United States of America v. Usama bin Laden, et al., March 19, 2001, http://cryptome.org/usa-v-ubl19.htm (discussion of Khalfan Khamis Muhamed). Members of Jemaah Islamiyah who studied in Afghanistan with Abdullah Azzam (Bin Laden's mentor and originator of the term al-Qaeda al-sulbah [the strong base]) and who over the years met 
with bin Laden and hosted September 11 mastermind Khalid Sheikh Muhammad, also tell me they never heard the term "Al Qaeda" applied to an organization until after September 11.

24. Robert Leiken, "Bearers of Global Jihad? Immigration and National Security After 9/11," March 25, 2004, http://www.nixoncenter.org/publications/monographs/ Leiken_Bearers_of_Global_Jihad.pdf.

25. Sageman, Understanding Terror Networks. Our research team has been updating Sageman's database with several hundred entries, and we find the demographic and networking trends fairly constant.

26. For more information on youth and the Internet, see "European Youth Ditching TV and Radio for Web," European Tech Wire, June 24, 2005, http:/www.europeantechwire.com/ etw/2005/06/24/. For more information on interpersonal communications through the Internet, see Paul Resnick and Richard Zeckhauser, "Trust Among Strangers in Internet Interactions," in Advances in Applied Microeconomics 11, ed. Michael Baye (Amsterdam: Elsevier Science, 2002).

27. Luis Miguel Ariza, "Virtual Jihad: The Internet as the Ideal Terrorism Recruiting Tool," Scientific American, January 2006, http://www.sciam.com/article.cfm? articleID=000B5155-2077-13A8-9E4D83414B7F0101.

28. Al-Farouq jihadi forum, October 7, 2005, http://www.Al-farouq.com/vb/.

29. Raymond Bonner, Don Van Natta, and Stephen Grey, "Investigators So Far Find Little Foreign Involvement," New York Times, July 31, 2005, p. A1.

30. Scott Atran, "The Jihadist Mutation," Jamestown Terrorism Monitor, March 25, 2004, http://www.jamestown.org/publications_details.php?volume_id $=400 \&$ issue_id $=2929 \&$ \&article_id $=23646$.

31. See http://online2005.100free.com/.

32. Office of the Press Secretary, The White House, "President Addresses Nation, Discusses Iraq, War on Terror," June 28, 2005, http://www.whitehouse.gov/news/releases/2005/06/20050628-7.html.

33. Stephen Hadley and Frances Fragos Townsend, "What We Saw in London," New York Times, July 23, 2005, p. A13.

34. For a discussion of the "hates freedom" thesis, see Scott Atran, "Mishandling Suicide Terrorism," The Washington Quarterly 27, no. 3 (Summer 2004): 67-90.

35. Al Jazeera, October 29, 2003. See Al Jazeera, November 28, 2003 (Ayman AlZawahiri).

36. Michael Scheuer, Imperial Hubris (Dulles, Va.: Potomac Books, 2004).

37. Reuven Paz, "Yes to WMD: The First Islamist Fatwah on the Use of Weapons of Mass Destruction," PRISM Special Dispatches on Global Jihad 1, no. 1 (May 2003), http://www.e-prism.org/images/PRISM\%20Special\%20dispatch\%20no\%201.doc.

38. Ayman Al-Zawahiri, Knights Under the Prophet's Banner, serialized in Al-Sharq AlAwsat (London), December 2-10, 2001, trans. Foreign Broadcast Information Service, FBIS-NES-2001-1202.

39. Sheikh Hamed Al-Betawi, interview with author, Nablus, West Bank, September 2004.

40. Jessica Stern, "Beneath Bombast and Bombs, a Caldron of Humiliation," Los Angeles Times, June 6, 2004, p. M1.

41. “[Al Qaeda]-Linked Militants Claim Responsibility for Resort Bomb," Ireland OnLine, July 23, 2005 (quoting Abdullah Azzam Brigades, "Al Qaeda in Syria and Egypt"). 
42. Mustafa Setmariam Nasar (also known as Abu Mus'ab Al-Suri), Da'wah lilMuqawamah Al-Islamiyyah Al-'Alamiyyah [A call for the Islamic global resistance], http: $/ /$ www.fsboa.com/vw/index.php? subject $=7 \&$ rec $=27 \&$ tit $=$ tit $\&$ pa $=0$.

43. Reuven Paz, "Al-Qaeda's Search for New Fronts: Instructions for Jihadi Activity in Egypt and Sinai," PRISM Special Dispatches on Global Jihad 3, no. 7, October 2005, http://www.e-prism.org/images/PRISM_no_7_vol_3_-_The_new_front_in_Egypt_ and_Sinai.pdf. See Abu Mus'ab Al-Suri, lecture, October 5, 2005, http:// z15.zupload.com:download.php?file $=$ getfile\&filepath $=1233$ (posted by the Global Islamic Media Front).

44. Scott Atran, In Gods We Trust (New York: Oxford University Press, 2002).

45. Alan Fiske and Phillip Tetlock, "Taboo Tradeoffs: Reactions to Transactions That Transgress the Spheres of Justice," Political Psychology 18 (1997): 255-297.

46. Max Weber, Economy and Society (Berkeley, Calif.: University of California Press, 1978).

47. Atran, "Emir."

48. R. Nisbett and D. Cohen, The Culture of Honor: Psychology of Violence in the South (Boulder, Colo.: Westview Press, 1996); J. Peristiani, ed., Honor and Shame: The Values of Mediterranean Society (Chicago: University of Chicago Press, 1966).

49. See Atran, "Mishandling Suicide Terrorism" (discussion of support for suicide attack rising as a function of roadblocks).

50. National Security Strategy of the United States, September 2003, introduction, http:// www.whitehouse.gov/nsc/nss.html.

51. Christopher Layne, "From Preponderance to Offshore Balancing: U.S. Grand Strategy in the Twenty-first Century," International Security 22, no. 1 (Summer 1997): 86-124; Christopher Layne, "Offshore Balancing Revisited," The Washington Quarterly 25, no. 2 (Spring 2002): 233-248.

52. Sageman, data presented to World Federation of Scientists Permanent Monitoring Panel on Terrorism, Erice, Italy, May 8, 2005.

53. Scott Atran, "Risk in the Wild: Reassessing Terrorist Threats From the Field" (presentation, American Association for the Advancement of Science, St. Louis, Mo., February 19, 2006).

54. Nasir Abas, Membongkar Jamaah Islamiyah [Unveiling Jemmah Islamiyah] (Jakarta: Grafindo Khazanah Ilmu, 2005), pp. 221, 316.

55. Porter J. Goss, "Global Intelligence Challenges 2005: Meeting Long-Term Challenges With a Long-Term Strategy," testimony before the Senate Select Committee on Intelligence, February 16, 2005, http://www.cia.gov/cia/public_affairs/speeches/ 2004/Goss_testimony_02162005.html.

56. Edwin Meese, remarks to the Critical Incident Analysis Group, Charlottesville, Va., April 3, 2005; Edwin Meese, e-mail communication with author, April 6, 2005.

57. See Ron Hassner, "Fighting Insurgencies on Sacred Ground," The Washington Quarterly 29, no. 2 (Spring 2006): 149-166.

58. Scott Atran, "In Indonesia, Democracy Isn't Enough," New York Times, October 5, 2005, p. A29.

59. Pew Research Center, “U.S. Image Up Slightly, but Still Negative," Pew Global Attitudes Project, June 2, 2003, http://pewglobal.org/reports/display.php?ReportID=185.

60. Pew Research Center, "Views of a Changing World," Pew Global Attitudes Project, June 23, 2005, http://pewglobal.org/reports/display.php?ReportID=247. 
